\title{
RH-LLW Disposal Facility Project CD-2/3 to Design/Build Proposal Reconciliation Report
}

June 2012

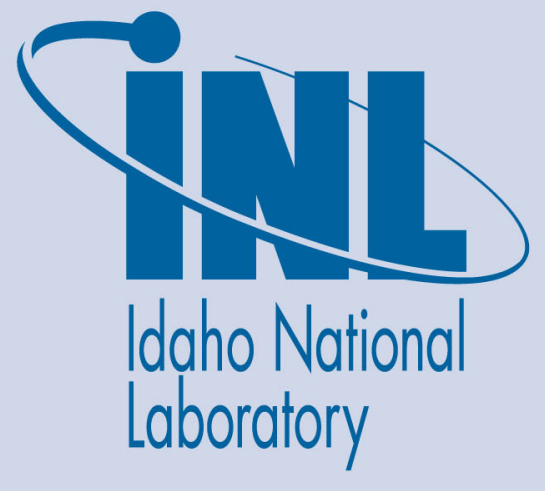

The INL is a U.S. Department of Energy National Laboratory operated by Battelle Energy Alliance 


\section{DISCLAIMER}

This information was prepared as an account of work sponsored by an agency of the U.S. Government. Neither the U.S. Government nor any agency thereof, nor any of their employees, makes any warranty, expressed or implied, or assumes any legal liability or responsibility for the accuracy, completeness, or usefulness, of any information, apparatus, product, or process disclosed, or represents that its use would not infringe privately owned rights. References herein to any specific commercial product, process, or service by trade name, trade mark, manufacturer, or otherwise, does not necessarily constitute or imply its endorsement, recommendation, or favoring by the U.S. Government or any agency thereof. The views and opinions of authors expressed herein do not necessarily state or reflect those of the U.S. Government or any agency thereof. 


\section{RH-LLW Disposal Facility Project CD-2/3 to Design/Build Proposal Reconciliation Report}

June 2012

Idaho National Laboratory Idaho Falls, Idaho 83415

http://www.inl.gov

Prepared for the

U.S. Department of Energy

Office of Nuclear Energy

Under DOE Idaho Operations Office

Contract DE-AC07-05ID14517 



\section{EXECUTIVE SUMMARY}

A reconciliation plan was developed and implemented to address potential gaps and responses to gaps between the design/build vendor proposals and the Critical Decision-2/3 approval request package for the Remote-Handled Low-Level Waste Disposal Facility Project. The plan and results of the plan implementation included development of a reconciliation team comprised of subject matter experts from Battelle Energy Alliance and the Department of Energy Idaho Operations Office, identification of reconciliation questions, reconciliation by the team, identification of unresolved/remaining issues, and identification of follow-up actions and subsequent approvals of responses. The plan addressed the potential for gaps to exist in the following areas:

- Department of Energy Order 435.1, "Radioactive Waste Management," requirements, including the performance assessment, composite analysis, monitoring plan, performance assessment/composite analysis maintenance plan, and closure plan

- Environmental assessment supporting the National Environmental Policy Act

- Nuclear safety

- Safeguards and security

- Emplacement operations

- Requirements for commissioning

- General project implementation.

The reconciliation plan and results of the plan implementation are provided in a business-sensitive project file. This report provides the reconciliation plan and non-business sensitive summary responses to identified gaps. 


\section{CONTENTS}

EXECUTIVE SUMMARY iii

ACRONYMS vii

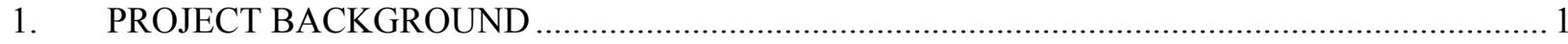

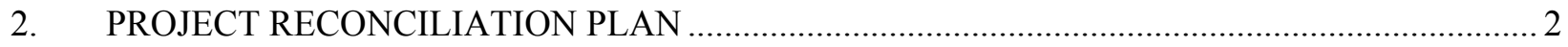

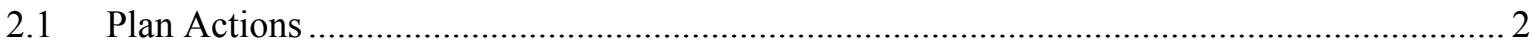

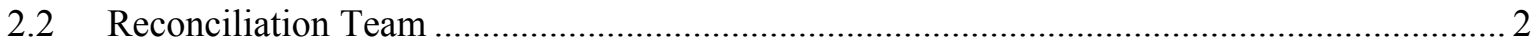

2.3 Reconciliation Review (Gap Analysis) Focus ….............................................................. 3

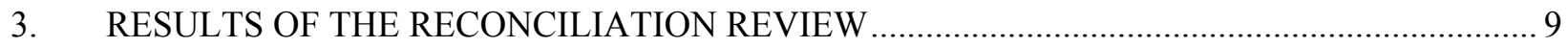

3.1 DOE Order 435.1 Performance Assessment and National Environmental Policy Act Environmental Assessment Gap Analyses ........................................................................ 9

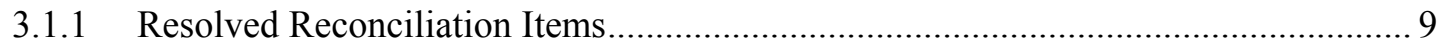

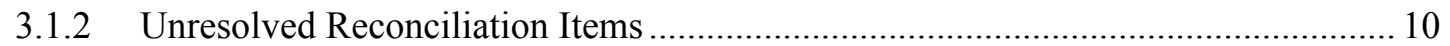

3.1.3 Issues to be Tracked through Final Design or Operations ...................................... 10

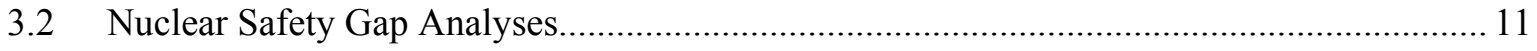

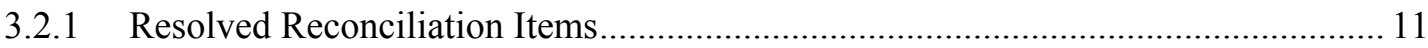

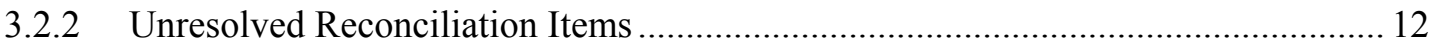

3.2.3 Issues to be Tracked through Final Design or Operations ...................................... 12

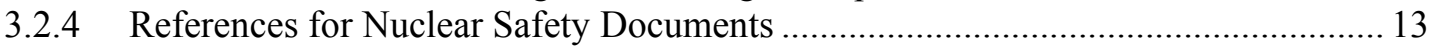

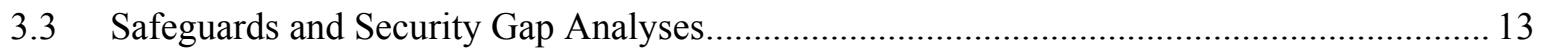

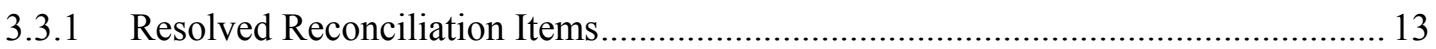

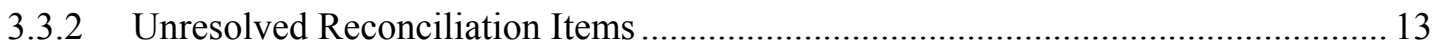

3.3.3 Issues to be Tracked through Final Design or Operations ....................................... 14

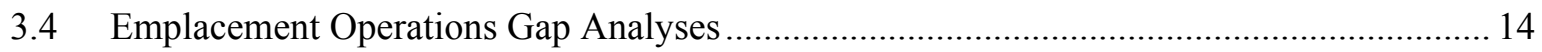

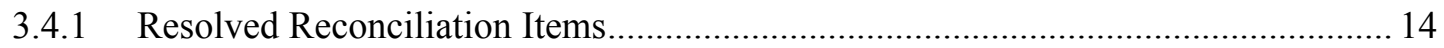

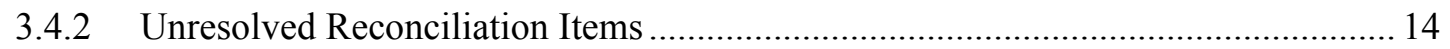

3.4.3 Issues to be Tracked through Final Design or Operations ....................................... 14

3.5 Requirements for Commissioning Gap Analyses .................................................... 14

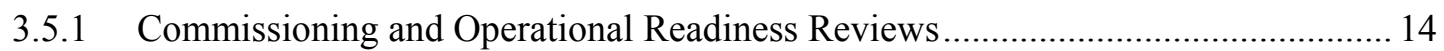

3.5.2 Requirements Development for the Transitions to Operations Plan ......................... 16

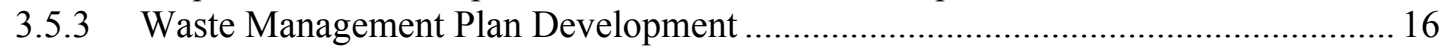

3.5.4 Issues to be Tracked through Final Design or Operations ...................................... 18 
3.6 General Project Implementation Gap Analyses ........................................................ 18

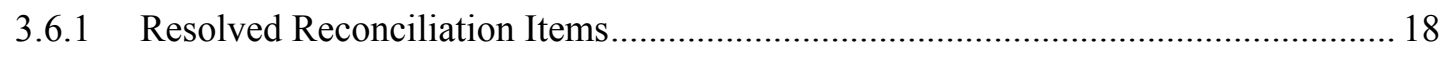

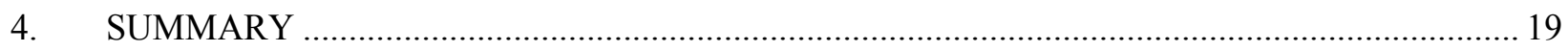

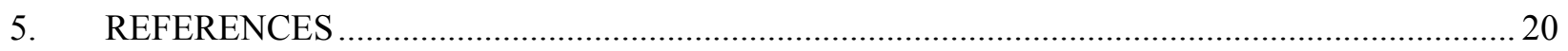

FIGURES

1. Example waste generator, transportation systems, waste management, and overarching DOE Order 435.1 and nuclear safety requirements 17

\section{TABLES}

1. Subject matter experts involved in the reconciliation review ................................................... 3

2. Topical focus of the remote-handled low-level waste Critical Decision-2/3 project baseline comparison to design-build vendor responses ............................................................. 4

3. Programs and plans required by DOE Order 425.1D for startup of Hazard Category 2 nuclear facilities. 15

4. Division of responsibility between the design/build vendor and Battelle Energy Alliance to support facility operational readiness. 15 


\section{ACRONYMS}

BEA Battelle Energy Alliance

CA composite analysis

CD critical decision

CVAS cask-to-vault-adapting system

DOE Department of Energy

LFRG LLW disposal facility federal review group

LLW low-level waste

NEPA National Environmental Policy Act

PA performance assessment

PSDR preliminary safety design report

RH remote-handled

SSCs systems, structures, and components 


\section{RH-LLW Disposal Facility Project CD-2/3 to Design/Build Proposal Reconciliation Report}

\section{PROJECT BACKGROUND}

During the design-build acquisition of the Remote-Handled Low-Level Waste (RH-LLW) Disposal Facility, a Critical Decision (CD)-2/3 approval request package was developed, consisting of Department of Energy (DOE) Order 413.3B, "Program and Project Management for the Acquisition of Capital Assets," required documents, in addition to a reference facility design concept and all supporting analyses for the National Environmental Policy Act (NEPA), long-term disposal facility performance, nuclear safety, operability, and security. These analyses helped to establish a facility design performance envelope and determine the scope of the planned acquisition.

In March 2012, bids were received for the design and construction of the RH-LLW Disposal Facility. These are firm-fixed price, design/build bids to design and construct a facility with sufficient disposal capacity to meet key scope requirements and provide the maximum disposal capacity possible for a given price ceiling of $\$ 35$ Million.

Deemed a build-to-budget project, the infrastructure supporting the facility was bid purely to a performance specification. However, because the below-grade vault system disposes of highly radioactive waste, the system was categorized as a Hazard Category 2 nuclear facility. To prevent deviation from design requirements that were analyzed and found to confirm acceptable nuclear facility performance, the vault system performance specification was highly detailed to yield a design that very closely matched the reference concept. However, to allow some innovation and development of cost efficiencies, selected design parameters were allowed flexibility, which may have the potential to affect the following facility issues and/or documents:

- DOE Order 435.1. "Radioactive Waste Management," requirements, including the performance assessment (PA), composite analysis (CA), monitoring plan, PA/CA maintenance plan, and closure plan

- Environmental assessment supporting NEPA

- Nuclear safety

- Safeguards and security

- Operability

- Requirements for commissioning

- General project implementation.

The design and implementation flexibility allowed by SPC-1437 (2012) and TFR-483 (2012) were considered by appropriate subject matter experts to be acceptably bounded by the limits established in TFR-483 and SPC-1437, given the range of configurations considered at the time the performance specifications were written. In conjunction with development of the performance specifications and consistent with the conceptual design forming their bases, the CD-2/3 approval request documents, which present project scope, schedule, cost and risk, were developed.

Consistent with the design/build approach, the advanced conceptual designs submitted as part of the bid package had varied design parameters assumed in the reference design. Operating assumptions and assumptions relating to needed ancillary equipment also were varied. 
Because approval of both CD-2 and CD-3 are being simultaneously sought for subcontract designs that have not yet been finalized and for which project operations (e.g., commissioning, waste management, and equipment provided) parameters were assumed, it became necessary to reconcile the design/build proposed actions to the CD-2/3 project baseline.

\section{PROJECT RECONCILIATION PLAN}

A reconciliation plan was developed to ensure the complete CD-2/3 documentation (especially the performance baseline) does not contain scope, schedule, cost, or risk gaps introduced by potential differences between the design/build proposed actions and the CD-2/3 project baseline. Gaps in this respect could include missing analyses, regulatory approvals, equipment, procedures, or plans.

\subsection{Plan Actions}

In order to ensure all gaps are covered between the design/build vendor proposals and the CD-2/3 project baseline, the following reconciliation steps were performed:

1) A reconciliation team was formed, consisting of subject matter experts in the areas potentially impacted by the design/build vendor proposals.

2) Technical review criteria were established based on information provided to the design/build vendors with the request for proposals, including the technical and functional requirements (TFR-483) and facility performance specification (SPC-1437).

3) Design/build vendor proposals were assessed relative to the review criteria for technical content and programmatic impact (i.e., impact to the scope, schedule, cost baseline, or risks) captured in the CD-2/3 approval request package.

4) Response actions were identified and incorporated into the CD-2/3 approval request package for differences that could be resolved prior to the Source Evaluation Board to design/build vendor interviews to ensure the CD-2/3 approval request package was enveloping. These response actions included identification of future tracking actions.

5) Unresolved technical questions were compiled for submittal to the design/build vendors prior to and during the one-on-one Source Evaluation Board design/build vendor interviews.

6) Based on the results of the Source Evaluation Board design/build vendor interviews, additional response actions were identified and incorporated into the CD-2/3 approval request package.

7) Results of the reconciliation were summarized in the plan and compiled into this non-business sensitive report for dissemination to future project reviews.

Any future identified differences between the design/build vendor proposals and the evolving CD-2/3 package will be similarly added to the reconciliation plan and to this non-business sensitive report. Acceptance of the reconciliation responses will be achieved upon periodic review of the reconciliation plan and reported by the Battelle Energy Alliance, LLC (BEA) project manager and the federal project director.

\subsection{Reconciliation Team}

The initial identification of potential gaps was developed jointly by the BEA and DOE subject matter experts identified as the principal points of contact. The principle points of contact are provided in Table 1. 
Table 1. Subject matter experts involved in the reconciliation review.

\begin{tabular}{lll}
\hline \multicolumn{1}{c}{ Subject Matter Area } & \multicolumn{1}{c}{ BEA Subject Matter Experts } & DOE Subject Matter Expert \\
\hline DOE Order 435.1 Requirements & Annette Schafer & Julie Conner \\
NEPA & Annette Schafer/John Irving & Jack Depperschmidt \\
Nuclear Safety & Boyd Christensen & Charles Maggart \\
Safeguards and Security & Chris Heyer & Dee Brown \\
Operability Requirements & Larry Evans & Julie Conner \\
Commissioning & Lisa Harvego & Gerardo Islas-Rivera \\
General Project Implementation & David Duncan & Julie Conner \\
\hline
\end{tabular}

\subsection{Reconciliation Review (Gap Analysis) Focus}

The reconciliation was focused on doing the following:

- Identifying the bases of assumptions used in the CD-2/3 approval request documents.

- Assessing whether the design/build vendor met the CD-2/3 assumptions or made different assumptions that might affect the project baseline, including, but not limited to, the following:

- Vault disposal capacity and the need for additional systems, structures, and components (SSCs) and all approvals and reviews

- Operating plans and procedures

- Required equipment, equipment design, equipment operating procedures, and equipment certification

- Additional technical analyses and approvals, including those by DOE

- Building or other code requirements, applicable standards, laws, and DOE requirements beyond those identified in developing CD-2/3.

- Determining how to reconcile the differences in assumptions

- Determining the impact of reconciliation on scope, schedule, budget, and risk that is used to determine the $\mathrm{CD}-2 / 3$ project baseline, management reserve, and contingency.

- Developing an implementation plan for addressing the differences between the design/build proposal and the CD-2/3 package (i.e., when does it need to be finished and who is responsible).

- Verifying implementation to ensure that changes and results have not adversely impacted other activities in the CD-2/3 package.

A summary of the environmental assessment, nuclear safety, safeguards and security, and operability technical topical areas covered by the gap analysis is provided in Table 2 . The results of the entire gap analysis, including the technical topical areas, are provided in Section 3. 
Table 2. Topical focus of the remote-handled low-level waste Critical Decision-2/3 project baseline comparison to design-build vendor responses.

\begin{tabular}{|c|c|c|}
\hline \multirow[t]{2}{*}{ Number } & Requirement & Assumption Basis in CD-2/3 Planning Documents \\
\hline & \multicolumn{2}{|c|}{ DOE 435.1 PA Requirements and EA Analyses Supporting the NEPA Finding of No Significant Impact } \\
\hline 1 & $\begin{array}{l}\text { Concrete mix design, hydraulic and transport properties, } \\
\text { and test plans will be provided by design/builder in } \\
\text { sufficient time for evaluation of the following: } \\
\text { - A longevity period of } 500 \text { years } \\
\text { - Degradation for radiolysis, chemical degradation, } \\
\text { biologic degradation, and formation of gases } \\
\text { - Freeze-thaw potential } \\
\text { - Sulfate reaction, ASR, and carbonation } \\
\text { - Impact on corrosion } \\
\text { - Radionuclide transport characteristics (e.g., } \\
\text { permeability, porosity, and diffusivity) } \\
\text { Review and acceptance during final design by the LLW } \\
\text { disposal facility federal review group (LFRG) of the } \\
\text { proposed concrete to be used in the vaults is required. }\end{array}$ & $\begin{array}{l}\text { SPC- } 1437 \text { requires the mix design and hydraulic transport properties be provided. } \\
\text { This needs to be provided early in the design stage to allow at least } 3 \text { weeks for the } \\
\text { analysis, followed by a design review by the LFRG. } \\
\text { It was assumed in SPC- } 1437 \text { that mix design will be made available at the start of final } \\
\text { design. The evaluation will include an LFRG review. The LFRG review will be initiated } \\
\text { prior to start of final design (model review). Model development will begin in January } \\
\text { prior to final design. } \\
\text { The CD-2/3 scope did not include an LFRG review at this stage. It is assumed that the } \\
\text { LFRG review will be funded by DOE. } \\
\text { Details are provided in Section } 2 \text { of "Explanation of the Liner Alternatives Analysis } \\
\text { Update Work Scope." } \\
\text { Our schedule shows start of model development on February 1, 2013. Concrete mix } \\
\text { design analysis March } 1 \text { through July } 1 \text { to include LFRG participation. }\end{array}$ \\
\hline
\end{tabular}




\begin{tabular}{|c|c|c|}
\hline Number & Requirement & Assumption Basis in CD-2/3 Planning Documents \\
\hline 3 & $\begin{array}{l}\text { Vault sizes and liner sizes used in the calculations and all } \\
\text { infill material will be specified, allowing verification of the } \\
\text { liner-to-vault void space. }\end{array}$ & $\begin{array}{l}\text { SPC-1437 and addenda placed limits on void space. Verification will require re- } \\
\text { calculation using exact sizes assumed by the vendor. This information also is required to } \\
\text { feed the turnover to operations plan. } \\
\text { No stabilizing plates (see SPC-1437 addenda) were assumed in the liner sizes given in } \\
\text { TFR-483. } \\
\text { The evaluation of materials is accounted for in Cost Estimate 9A28-H4, Level 1.1.40(1- } \\
\text { 12). }\end{array}$ \\
\hline 6 & $\begin{array}{l}\text { The vault shield plug will be removable, will provide } \\
\text { shielding for operations, will withstand freeze-thaw } \\
\text { conditions, and will provide a weight-bearing surface for } \\
\text { operations. }\end{array}$ & $\begin{array}{l}\text { SPC-1437 assumes the same concrete mix will be used for the plug as for vault walls and } \\
\text { base. Assessment of mix design should assure this. BEA assumed only the tops of vault } \\
\text { walls and plugs would be subject to the frost-line. }\end{array}$ \\
\hline 7 & $\begin{array}{l}\text { Vault bases will provide structural stability for all loading } \\
\text { conditions, will enable water egress, and will prevent } \\
\text { settlement. }\end{array}$ & $\begin{array}{l}\text { SPC-1437 assumes the same concrete mix used for the plugs and walls will be used for } \\
\text { the vault bases. Also, the vault bases are assumed to provide aerially distributed drainage } \\
\text { (i.e., shower head effect). Vault bases are assumed to drain freely (holes in bases). }\end{array}$ \\
\hline 8 & $\begin{array}{l}\text { Accommodation of a } 2 \text {-ft interim soil cover for covering } \\
\text { vaults as they are filled. }\end{array}$ & $\begin{array}{l}\text { SPC-1437 assumed a layout similar to that in use at the Radioactive Waste Management } \\
\text { Complex, where the vaults are filled along the long axis and where all vaults were the } \\
\text { same size, regardless of waste liner size. } \\
\text { This allows the Radioactive Waste Management Complex to cover the filled vaults as } \\
\text { they go. }\end{array}$ \\
\hline
\end{tabular}




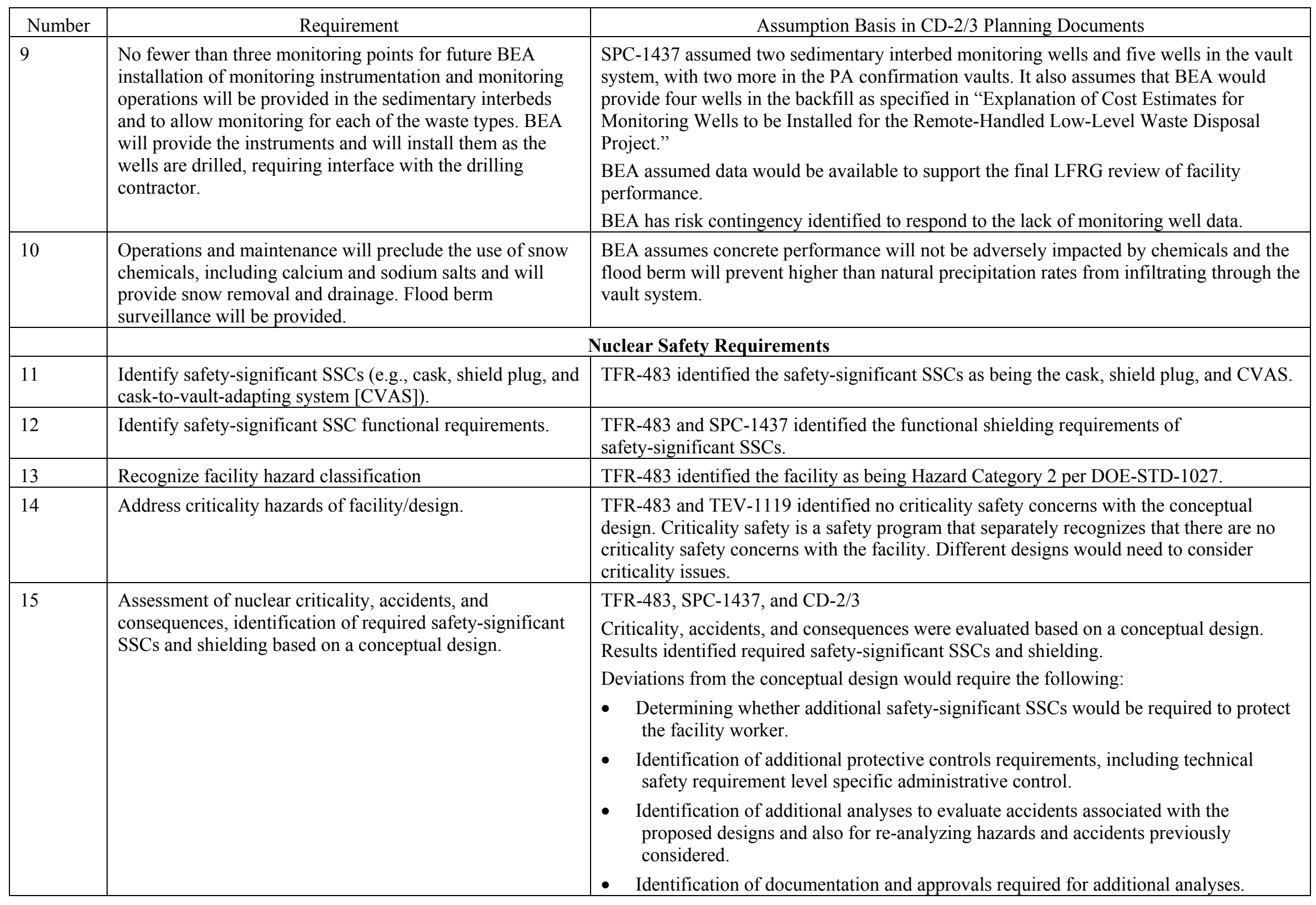




\begin{tabular}{|c|c|c|}
\hline Number & Requirement & Assumption Basis in CD-2/3 Planning Documents \\
\hline & \multicolumn{2}{|c|}{ Operability and Requirements for Commissioning } \\
\hline 16 & $\begin{array}{l}\text { Material handling equipment necessary to emplace the } \\
\text { waste canisters in the vaults (minus the transportation } \\
\text { equipment and Manitowoc crane). }\end{array}$ & $\begin{array}{l}\text { See SPC-1437, Section E.1.A.3 (page } 139 \text { of 260) } \\
\text { Design/build vendor is required to provide material handling equipment necessary to } \\
\text { emplace the waste canisters in the vaults (minus the transportation equipment and } \\
\text { Manitowoc crane). }\end{array}$ \\
\hline 17 & Operations and maintenance procedures. & $\begin{array}{l}\text { SPC-1437 } \\
\text { Radioactive Waste Management Complex vendor is required to provide operations and } \\
\text { maintenance procedures. }\end{array}$ \\
\hline 19 & Operational readiness review. & $\begin{array}{l}\text { SPC-1437 } \\
\text { Design/build vendor must perform an operational readiness review. }\end{array}$ \\
\hline 20 & DOE operational readiness review. & $\begin{array}{l}\text { SPC-1437 } \\
\text { Design/build vendor must support the conduct of a DOE operational readiness review. }\end{array}$ \\
\hline 22 & Year-round operations. & $\begin{array}{l}\text { SPC-1437 } \\
\text { Design/build vendor design will accommodate year-round operations. }\end{array}$ \\
\hline 23 & Plug design for removal. & $\begin{array}{l}\text { SPC-1437 } \\
\text { Plug will be removable (multiple cycles) without affecting integrity of adjacent vaults and } \\
\text { plugs. }\end{array}$ \\
\hline 24 & Lifting requirements for the shield plug. & $\begin{array}{l}\text { SPC-1437 } \\
\text { Shield plugs will have a minimum of three lifting points per plug. }\end{array}$ \\
\hline 25 & $\begin{array}{l}\text { Operations shall accommodate the use of the existing } \\
\text { transportation equipment (e.g., casks and Naval Reactors } \\
\text { Facility 55-Ton CVAS) and Manitowoc crane. }\end{array}$ & $\begin{array}{l}\text { SPC-1437 } \\
\text { Operations will accommodate the use of the existing transportation equipment (e.g., casks } \\
\text { and Naval Reactors Facility 55-Ton CVAS) and Manitowoc crane. }\end{array}$ \\
\hline 26 & $\begin{array}{l}\text { Vaults shall accommodate disposal of the waste canisters } \\
\text { described in TFR-483, Table } 1 \text { (February 23, } 2012 \\
\text { revision). }\end{array}$ & $\begin{array}{l}\text { SPC-1437 } \\
\text { Vaults will accommodate disposal of the waste canisters described in TFR-483, Table } 1 \\
\text { (February 23, } 2012 \text { revision). }\end{array}$ \\
\hline
\end{tabular}




\begin{tabular}{|c|c|c|}
\hline Number & Requirement & Assumption Basis in CD-2/3 Planning Documents \\
\hline & \multicolumn{2}{|c|}{ Safeguards and Security Requirements } \\
\hline 27 & Perimeter security fence specifications. & See SPC-1437, page 145 \\
\hline 28 & $\begin{array}{l}\text { Access control requirements for the entrances/exits, } \\
\text { including locks and doors for the temporary storage } \\
\text { facility. }\end{array}$ & TFR-483, page 18 and SPC-1437, page 133 \\
\hline 29 & $\begin{array}{l}\text { Access control requirements for personnel accessing the } \\
\text { vaults and casks during operations. }\end{array}$ & TFR-483, page 18 and SPC-1437, page 256 \\
\hline 31 & $\begin{array}{l}\text { Vault loading operations, ensuring permanent security of } \\
\text { the liner after emplacement. }\end{array}$ & $\begin{array}{l}\text { TFR- } 483 \text {, page } 18 \text { and SPC-1437, page } 140 \\
\text { The performance specifications include requirements to ensure the lifting device for the } \\
\text { cask liner containing classified waste shall be designed to require specialized equipment } \\
\text { or alternate equipment not readily available and will require more than one person to } \\
\text { operate, resulting in a significant increase of time required to reattach the lifting device to } \\
\text { the cask liner once it is lowered into the vault. The increase in time and difficulty in } \\
\text { reattaching the lifting device to the liner once it is in the vault decreases the probability of } \\
\text { gaining access to the classified matter within the liner. }\end{array}$ \\
\hline 32 & $\begin{array}{l}\text { Liner design and discharge design, allowing securing the } \\
\text { lifting attachments or other protection measures to ensure } \\
\text { the liner and contents are not retrievable. }\end{array}$ & $\begin{array}{l}\text { Preliminary Security Vulnerability and Physical Protection Assessment of Proposed } \\
\text { Remote-Handled Low-Level Waste Disposal Facility (INL/INT-11-21259) requires } \\
\text { protection of the liner contents. }\end{array}$ \\
\hline 33 & Crane operations, ensuring boom or gantry security & $\begin{array}{l}\text { Preliminary Security Vulnerability and Physical Protection Assessment of Proposed } \\
\text { Remote-Handled Low-Level Waste Disposal Facility (INL/INT-11-21259) requires that } \\
\text { the boom and gantry cranes be secured when not in use. }\end{array}$ \\
\hline 34 & Temporary waste shipment storage building security. & $\begin{array}{l}\text { TFR-483, page } 18 \text { and SPC-1437, page } 133 \\
\text { Specifications include the types of doors used for accessing the temporary waste shipment } \\
\text { storage building to provide the required protection requirements (e.g., BMS on pedestrian } \\
\text { doors and lockout of roll-up doors as applicable in their design). } \\
\text { Additional requirements include protection for operational use of the temporary waste } \\
\text { shipment storage building in the event a cask is not immediately unloaded into a vault. }\end{array}$ \\
\hline
\end{tabular}




\section{RESULTS OF THE RECONCILIATION REVIEW}

The following subsections contain a summary of the subject matter expert actions taken to reconcile the design/build proposals to the CD-2/3 documentation package, identify remaining unresolved items, and track issues through project design and completion.

\subsection{DOE Order 435.1 Performance Assessment and National Environmental Policy Act Environmental Assessment Gap Analyses}

Interfaces between the conceptual design, used as the basis for the facility PA, and the environmental assessment fulfilling the requirements of DOE Order 435.1 and NEPA, were previously identified in Assessment of Potential Risks and Mitigation for DOE O 435.1 Requirements and the NEPA Finding of No Significant Impact (FONSI) (INL 2012c). The assessment of risks was developed to ensure the project baseline was adequate going forward to $\mathrm{CD}-2 / 3$, and that project risks related to environmental requirements were minimized early in development of the supporting documents and analyses. As explained in the risk assessment plan for environmental analyses, there will be a required LFRG review during the final design stage to evaluate the concrete mix design and hydraulic infiltration characteristics.

In order to facilitate the intermediate LFRG review and final review, activities were identified to provide assessment of the design/bid contractor concrete mix design and hydraulic performance. These activities include calculation of the following:

- Degradation rate of the vault system (concrete degradation rates), determining the period of structural stability:

- Its impact on the resultant longevity of the final cover due to subsidence and collapse of the vault system

- Impact on the geochemical environment beneath the vault system.

- Hydraulic ponding potential and potential impact to operations

- Groundwater concentrations and doses relevant to the PA and NEPA groundwater impacts analysis.

These activities are outlined in Explanation of the Liner Alternatives Analysis Update Work Scope provided to support cost element activity C.R.60.20.04.05.01.

Activities also were factored into the project baseline that were focused on meeting the conditions placed on the disposal authorization statement as a result of the LFRG review of the PA. These activities include an assessment of the as-built facility performance. This will be done through a combination of data collection and modeling. Instrumentation and monitoring wells are discussed in Explanation of Cost Estimates for Monitoring-Wells to be Installed for the Remote-Handled Low-Level Waste Disposal Project (cost elements RHA100, RHA110, and RH3150 in C.R.60.20.20.04.2.2). Data analyses required to assess the monitoring results are discussed in Explanation of Work Supporting 435.1 Documentation Leading to the Final DAS and are shown in cost elements C.R.60.20.03.5.2 (RH4480, RH4490, and RH7010).

This supporting work scope, SPC-1437, and TFR-483 allowed reconciliation between the design/build vendor and CD-2/3 submittal documentation package. This reconciliation report provides a summary of the resolved reconciliation items and the outstanding issues.

\subsubsection{Resolved Reconciliation Items}

- The required LFRG review of the concrete design and hydraulic properties could impact the design/build vendor schedule. Scope, schedule, and funding have been identified for BEA involvement in the liner alternatives analysis that will be used to assess the concrete and hydraulic performance of the vault system. Additional resources were allocated to allow for a combined 
concrete and hydraulic property evaluation and interface during design. If schedule acceleration occurs at award of the subcontract, additional BEA resources may be needed. A design/build schedule risk with residual impacts has been added to accommodate this possibility.

- The participation of the LFRG in review of this analysis was assumed to be funded by DOE. Participation in the overall final vault design process for the PA preparation team was assumed to be captured in the additional resources allocated above. Assessment of the final concrete and hydraulic parameters has been factored into this resource allocation. It is expected to be much more intensive than the design reviews supporting the component-to-component infiltration assessment. This assessment also will help ensure that structural calculations are consistent with the bases assumed in the $\mathrm{CD}-2 / 3$ documentation.

- After contract award, close coordination with the drilling subcontractor will be necessary to ensure that instrumentation will be installed during well completion.

- The potential for changes to the vault layout to be accommodated during final design was assessed during the Source Evaluation Board design/build vendor interviews. Potential layout issues include depth and horizontal placement within the 45 -acre area. The largest issue related to vault layout is the proposed height of the shield plugs above grade, which increases the potential for freeze-thaw cracking of the safety-significant SSC.

Freeze-thaw cracking can be reduced through air entrainment, which reduces the bulk concrete density used in the calculation of shielding, potentially requiring thicker plugs. Alleviating the freeze-thaw potential could create the need for additional excavation during construction to lower the height of the shield plug, which would reduce the need to provide additional freeze/thaw resistance in the concrete mix design. The potential for this additional scope and cost has been accounted for by increasing the residual impact probability of Risk \#60 from 35 to 50\%. This increases management reserve to cover the potential cost of additional excavation.

- An interim cover will be installed during facility operations as required by DOE Order 435.1. Specifications for the interim liner were not included in SPC-1437, although the structural requirement to support an interim liner was provided. In order to accommodate the interim liner, an interim cover plan will be developed prior to the start of final vault design to ensure monitoring wells and the PA confirmation wells will not be affected by the interim cover.

- The performance specification does not explicitly require the inclusion of an interim cover to be installed during operations or to be included in the final design. An additional question was posed to the design/build vendors, asking whether their designs can accommodate the installation of an interim cover without adversely impacting waste emplacement operations, use of the PA confirmation vaults, or sampling of the monitoring wells. Long-term costs associated with future sampling could be greatly increased if location of the confirmation vaults and monitoring wells are not factored into the design of an interim cover. An interim cover will be incorporated into the vault system design, eliminating the need to consider an additional risk to accommodate this issue.

\subsubsection{Unresolved Reconciliation Items}

At the conclusion of the PA and NEPA reconciliation review, there were no remaining issues identified that cannot be addressed during final design.

\subsubsection{Issues to be Tracked through Final Design or Operations}

The following items are specific to those identified in the reconciliation plan and do not include the general requirements to assess facility performance previously identified and included in the project baseline: 
- Concrete design relative to nuclear safety requirements (i.e., density reduction through air-entrainment required to provide freeze-thaw protection)

- Final vault layout with appropriate consideration of the PA confirmation vault locations, monitoring well locations, and how the interim cover affects the interim and final facility closure plan

- Berm emplacement and potential impact to the NEPA commitments.

\subsection{Nuclear Safety Gap Analyses}

The preliminary safety design report (PSDR) (INL 2012) and conceptual safety design report (INL 2010b) were based on TFR-483, SPC-1437, and the conceptual design report (INL 2010a). The conceptual safety design report was developed to do the following:

- Document and establish the preliminary inventory of hazardous materials, including radioactive materials and chemicals

- Document and establish the preliminary hazard categorization of the proposed facility

- Identify and analyze primary facility hazards and facility design-basis accidents

- Provide an initial determination, based on the preliminary hazard analysis (INL 2010c), of safety-class and safety-significant SSCs

- Evaluate the security issues that can impact the facility safety basis

- Comply with the nuclear safety design criteria of DOE Order 420.1B, "Facility Safety."

The PSDR (INL 2012) provides an update to the information presented in the conceptual safety design report (INL 2010b). In addition, the PSDR discussed site characteristics that impact accident analysis, provided the facility and process information necessary to support the hazard analysis, identified and evaluated potential hazards for the processes associated with onsite handling and disposal of RHLLW, and discussed the need for safety features that will become part of the facility design.

The conceptual facility design used to develop SPC-1437 was similar to the design provided in the conceptual design report (INL 2010a). These analyses are configuration (design) dependent. Evaluation of the design/build vendor designs to assess the continued adequacy of the PSDR has been initiated based on differences identified through design reconciliation. This evaluation is provided as an addendum to the PSDR (INL 2012 as INL/EXT-10-19054-ADD-1). The addendum will be controlled as a business sensitive report until design/build contract award. Based on the analyses contained in the addendum, the reconciliation required to fulfill the needs of the CD-2/3 project documents to the design/build vendor's proposals was conducted.

\subsubsection{Resolved Reconciliation Items}

The design/build vendor proposals are likely to require an additional safety-significant SSC. The use of a temporary shield plug to protect the facility worker has been identified as safety-significant due to the consequences of high-radiation exposure during emplacement of multiple canisters within a single storage vault. It also is likely that a technical safety requirement, level-specific administrative control for transferring waste containers with high-contact exposure rates will be required. Separate analyses also will be required to evaluate accidents associated with the proposed disposal. Preliminary evaluations already performed have begun to provide assurance that the proposed designs are capable of meeting nuclear safety requirements. These evaluations will be documented in several formal safety and supporting documents. 
- The reconciliation review resulted in 160 hours being added to the project baseline to support nuclear safety analyses and review. Evaluations will be performed and documented within engineering calculation and analysis reports or as addenda to the preliminary safety documents as determined appropriate by the project management team.

- The CD-2/3 package was revised to allow development of documentation to account for expected impact associated with the proposed design changes with respect to nuclear criticality, accidents and consequences, new safety-significant SSCs, and shielding because the design/build vendor designs' represent a departure from the conceptual design upon which those factors were previously evaluated.

- Civil/structural project team members assessed the impact of the bidders' concepts for seismic qualification and felt that seismic qualification of their designs would not be affected by proposed concept differences.

\subsubsection{Unresolved Reconciliation Items}

Following the oral presentations, questions still remain about the bidders' understanding of the CVAS function and form as a safety-significant SSC. Risk \#35 was modified to increase residual probability from 35 to $45 \%$ to accommodate vendor interpretation errors during design and fabrication of the CVASs.

\subsubsection{Issues to be Tracked through Final Design or Operations}

Items listed here are specific to those identified in the reconciliation plan and do not include the general requirements to assess nuclear safety issues previously identified and included in the project baseline:

- Cask, CVAS, and vault designs are required in order to conduct the PDSA, which must be accepted prior to releasing the CVAS and vault system construction hold point. A modification to the baseline schedule was completed to allow the CVAS design to be developed in parallel with the vault design. However, the transportation cask design necessary to complete the CVAS design is scheduled to begin at a later date by the project funding profile. Requiring the cask designs prior to CVAS design would extend the project schedule by approximately 9 months and require modification of the capital funding request already submitted.

To resolve this issue without a schedule and funding profile modification, a cask-to-CVAS interface plan will be developed to allow DOE to review and accept the PDSA prior to finalizing the cask designs as required to lift the CVAS and vault construction hold points. The cask-to-CVAS interface plan will identify the requirements of the cask, including the following:

- $\quad$ Reducing direct radiation exposures to ALARA by providing sufficient shielding

- Allowing positioning of the modified FTC and HFEF-5casks during waste discharge

- Providing dimensional compatibility between all cask, CVAS, and vault interfaces.

The interface plan will act as the cask design when the PDSA is submitted for evaluation. The interface plan will include a checklist of plans, procedures, and analyses that will be required to be fulfilled by the interface agreement.

- The safety-significant SSC identified in the PSDR, in addition to any introduced safety-significant $\mathrm{SSC}$ requirements, must conform to functionality requirements. Corrective actions could include additional documentation/design from the design/build vendor and verification by the subject matter expert.

- Concrete design relative to nuclear safety requirements (density reduction through air-entrainment required to provide freeze-thaw protection) will be verified through final design. 


\subsubsection{References for Nuclear Safety Documents}

INL, 2010a, Conceptual Design Report for the Remote-Handled Low-Level Waste Disposal Project, INL/EXT-07-12901, Idaho National Laboratory, April 2010

INL, 2010b, Conceptual Safety Design Report for the Remote-Handled Low-Level Waste Disposal Project, INL/EXT-09-17427, Idaho National Laboratory, February 2010

INL, 2010c, Preliminary Hazard Assessment for the Remote-Handled Low-level Waste Disposal Facility, INL/EXT-07-12903, Idaho National Laboratory, April 2010

INL, 2012, Preliminary Safety Design Report for the Remote Handled Low-Level Waste Disposal Project, INL/EXT-10-19054, Idaho National Laboratory, March 2012

SPC-1437, 2012, "Design-Build-Operate Performance Specification for the Remote-Handled Low-Level Waste Disposal Project,” Project No. 31055, January 12, 2012

TFR-483, 2012, "Technical and Functional Requirements, Remote-Handled Low-Level Waste Disposal Project," Project No. 31055, January 16, 2012.

\subsection{Safeguards and Security Gap Analyses}

Assumptions regarding safeguards and security requirements were captured in TFR-483 (2012), SPC-1437 (2012), and the Preliminary Security Vulnerability and Physical Protection Assessment of Proposed Remote-Handled Low-Level Waste Disposal Facility (INL/INT-11-21259). There were no additional supporting analyses conducted.

\subsubsection{Resolved Reconciliation Items}

The reconciliation review suggests that the design/build vendors will comply with the requirements of SPC-1437 in the following areas, requiring no modifications to the CD-2/3 package. Most of the items listed here can and will be addressed during final design or prior to the operational readiness review.

- Crane operations, ensuring boom and gantry security

- Vault loading operations; removing/replacing vault shield plug

- Vault loading operations, ensuring permanent security of the liner after emplacement

- Liner design and discharge design, allowing securing the lifting attachments or other protection measures to ensure the liner and contents are not retrievable

- Perimeter security fence design

- Access control implementation for the entrances/exits, including locks and doors for the temporary storage facility

- Access control requirements for personnel accessing the vaults and casks during operations

- Temporary waste shipment storage building security

- Perimeter fence lighting.

\subsubsection{Unresolved Reconciliation Items}

There are no safeguards and security issues identified that cannot be addressed during final design. 


\subsubsection{Issues to be Tracked through Final Design or Operations}

All safeguards and security questions will be tracked through final design and commissioning.

\subsection{Emplacement Operations Gap Analyses}

Assumptions regarding emplacement operations were captured in SPC-1437, based on the assumption that similar emplacement methods and equipment currently in use at the Radioactive Waste Management Complex would be required by the design/build vendor's design. There were no additional supporting analyses conducted.

\subsubsection{Resolved Reconciliation Items}

The reconciliation review suggests that the design/build vendors will comply with the requirements of SPC-1437 in the following areas, which will require no modifications to the CD-2/3 package:

- Design shall accommodate year-round operations

- Removable plug able to be removed (multiple cycles) without affecting integrity of adjacent vaults and plugs

- Shield plugs have a minimum of three lifting points per plug

- Operations shall accommodate the use of the existing transportation equipment

- Vaults shall accommodate disposal of the waste canisters described in TFR-483, Table 1.

\subsubsection{Unresolved Reconciliation Items}

There were no unresolved general operability issues identified during the reconciliation review that cannot be addressed during final design.

\subsubsection{Issues to be Tracked through Final Design or Operations}

There are no operability issues to be tracked through final design that are not addressed as nuclear safety or requirements for commissioning activities.

\subsection{Requirements for Commissioning Gap Analyses}

Requirements regarding facility operations were provided in SPC-1437, including those related to equipment required for waste emplacement and general operations preparation. Additional requirements that are not the sole responsibility of the design/build vendor include those related to transition to operations, waste management, and generation of test plans and operating manuals required to support the contractor operational readiness review and the DOE operational readiness review.

\subsubsection{Commissioning and Operational Readiness Reviews}

One of the requirements listed in DOE Order 425.1D, "Verification of Readiness to Start Up or Restart Nuclear Facilities," is that a DOE operational readiness review must be conducted for the initial startup of a newly constructed nuclear facility having a new documented safety analysis and associated technical safety requirements.

For the startup of new Hazard Category 2 nuclear facilities, the DOE Order 425.1D requirements are consistent with the safety management programs identified in 10 CFR Section 830.204, "Documented Safety Analysis." These are shown in Table 3. Development of these programs and plans will proceed under the transition to operations plan. Operational transition activities are included in the project baseline and include development of facility operating procedures, functional testing of all facility systems and equipment, operations personnel training, spare parts procurement, operational readiness review activities, and facility commissioning that meets the requirement shown in Table 3. 
Table 3. Programs and plans required by DOE Order 425.1D for startup of Hazard Category 2 nuclear facilities.

\begin{tabular}{|l|l|}
\hline Quality Assurance Programs & Emergency Preparedness \\
\hline Procedures Management & Fire Protection Program \\
\hline Maintenance Management & Waste Management Program \\
\hline Personnel Training Program & Radiation Protection \\
\hline Conduct of Operations & Criticality Safety Program \\
\hline
\end{tabular}

The design/build vendor will assist in preparations for facility turnover. Project turnover and acceptance will be conducted in accordance with LWP-7460, "Project Turnover and Acceptance." A management self assessment (MSA), as well as contractor and DOE operational readiness reviews will be completed in accordance with LWP-9903, "Performing Management Self-Assessments for Readiness," and DOE Order 425.1C, "Startup and Restart of Nuclear Facilities." The MSA, Contractor operational readiness review (CORR), and DOE operational readiness review (ORR) will be completed in sequence. DOE Order $425.1 \mathrm{C}$ requires the operating contractor to notify DOE that readiness to startup has been verified by a CORR prior to initiation of the ORR.

Upon successful completion of the DOE ORR and closeout of all pre-start findings, DOE will authorize startup. Startup Approval Authority for new Hazard Category 2 facilities currently resides with the Secretary of Energy. It is possible this Authority may be delegated to NE prior to facility startup. Upon receipt of DOE's authorization to start operations, a draft project closure plan and project completion report will be developed. The draft plan and report will describe follow-on commitments and requirements (i.e., post project) needed to complete project closure. This documentation will be appended to the (already submitted) CD-4 documentation in order to allow AE approval of CD-4.

Table 4 identifies the specific activities (i.e., planning packages) currently in the project cost estimate and schedule to support operations readiness. The table shows the division of responsibility between the design/build vendor and BEA (in hours and dollars) for each activity included in the rolling planning process used for the project. The requirement to further detail these activities well in advance of execution has been identified under tracked items below.

Table 4. Division of responsibility between the design/build vendor and Battelle Energy Alliance to support facility operational readiness.

\begin{tabular}{|c|c|c|c|c|c|}
\hline WBS Level & WBS Description & BEA Labor & & $\begin{array}{l}\text { Design/Build } \\
\text { Vendor Labor }\end{array}$ & \\
\hline & & Mhrs & Cost & Mhrs & Cost \\
\hline C.R.60.20.02.3.1 & $\begin{array}{l}\text { Personnel } \\
\text { Training/Qualification }\end{array}$ & 684 & $\$ 124,000$ & 3,100 & $\$ 642,500$ \\
\hline C.R.60.20.02.3.2 & $\begin{array}{l}\text { Operations and Maintenance } \\
\text { Procedures }\end{array}$ & 652 & $\$ 145,505$ & 3,084 & $\$ 637,824$ \\
\hline C.R.60.20.02.3.3 & $\begin{array}{l}\text { Operational Readiness } \\
\text { Review }\end{array}$ & 2,240 & $\$ 486,066$ & 2,922 & $\$ 711,467$ \\
\hline \multirow[t]{2}{*}{ C.R.60.20.02.3.4 } & $\begin{array}{l}\text { Operations Turnover Fiscal } \\
\text { Year } 2016\end{array}$ & 240 & $\$ 47,718$ & 220 & $\$ 43,957$ \\
\hline & TOTALS & 3,816 & $\$ 803,289$ & 9,326 & $\$ 2,035,748$ \\
\hline
\end{tabular}




\subsubsection{Requirements Development for the Transitions to Operations Plan}

Requirements and interfaces supporting transition to operations are being developed. This plan addresses the need to identify potential gaps between the RH-LLW disposal facility project and non-project organizations, requirements, and interfaces. Gaps could be introduced, for example, by the need to develop steel waste liners (a generator activity) and the disposal equipment designed and implemented by the design/build vendor. The plan establishes a timeline for developing interfaces supporting transitions to operations as indicated in Figure 1. The timeline for requirements identification is Fiscal Year 2013, prior to beginning the final vault design.

\subsubsection{Waste Management Plan Development}

A plan for integration of RH-LLW management at the Idaho National Laboratory was initiated. This plan will outline scope, schedule, and budget requirements to integrate RH-LLW emplacement with planned waste preparation and shipment activities from each of the currently identified INL waste generator sites. This plan is required by DOE Order 425.1D and will help ensure that DOE Order 435.1 requirements have been met during operations. The waste management plan for the RH-LLW disposal facility assumes the following:

- Waste generators are responsible for waste characterization, including determination of radiological content by waste form; waste packaging (loading waste containers); providing transport casks and trailers; and delivering the transported waste to the RH-LLW disposal facility. It also is assumed they are responsible for facility-specific waste management plans governing waste generation, waste characterization, waste loading, and temporary storage.

- Waste Generator Services is responsible for assisting the generators in completing the Integrated Waste Tracking System database entries, waste certification, and waste tracking.

- Waste acceptance criteria development will be provided by the RH-LLW disposal facility as required by DOE Order 435.1. The waste acceptance criteria will specify containerization requirements, radiologic emissions limits (surface contact rates), radiologic inventory limits, etc.

- Waste is received by the facility, and the RH-LLW disposal facility waste management plan is responsible for tracking and maintaining the inventory of disposed of waste.

With these assumptions, an outline of the plan is presented below and will act as the structure for development of a Waste Management Program. Occurring, in parallel will be development of a business plan that will determine and organize the method for funding RH-LLW disposal operations and the Waste Management Program. Development of the Radioactive Waste Management Basis is considered to be within the scope of the project. All other activities identified in the waste management plan and business plan are outside of project scope.

The waste management plan will be developed in the fourth quarter of 2012 and will provide direction for establishment of an INL RH-LLW Management Program. This program will be established to support commencement of RH-LLW disposal operations following project CD-4 approval.

1. Management Approach

a. RH-LLW Program Management

1) Reflective of the INL Waste Management Program 10-year Strategy

b. RH-LLW Disposal Facility Waste Management Plan

2) Radioactive Waste Management Basis

a) Generation 


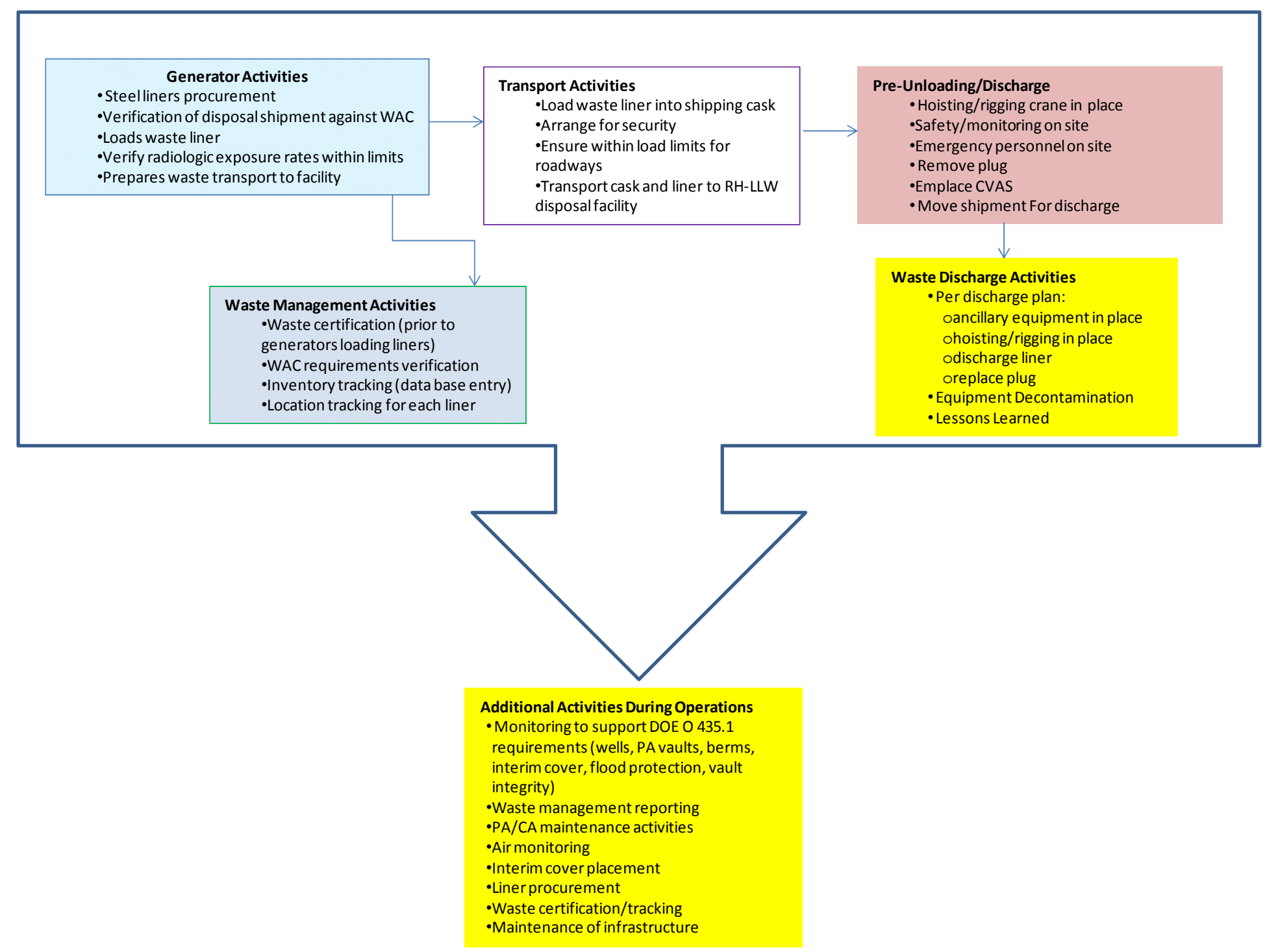

Figure 1. Example waste generator, transportation systems, waste management, and overarching DOE Order 435.1 and nuclear safety requirements. 

i. Waste Certification
ii. Transfer of Waste
iii. Waste Acceptance Criteria
iv. Verification Program
b) Treatment
c) Packaging and Storage
d) Disposal

3) Maintenance and Monitoring

4) Un-reviewed Waste Management Question Evaluation

5) Use of Off-site DOE and Non-DOE facilities

6) Facility Closure

c. Proposed Organization

d. Business Plan

e. Proposed Subcontracting Alternatives

f. Cost and Schedule

g. Unresolved Reconciliation Items.

It is not clear that the design/build vendors are providing all material-handling equipment necessary (minus the transportation equipment and Manitowoc crane) to emplace the waste canisters in the vaults. Project costs, including contingency, were adjusted to ensure project costs that are based the conceptual level of the vendor bids (e.g., equipment, vaults, and vehicles). (Project risk item \#66 addresses the potential for missing scope in the bids.)

\subsubsection{Issues to be Tracked through Final Design or Operations}

Issues identified for tracking by the gap analysis will be addressed through the transition to operations plan and commissioning plan, including the waste management plan.

\subsection{General Project Implementation Gap Analyses}

Assumptions regarding emplacement operations were captured in SPC-1437, based on the assumption that similar emplacement methods and equipment currently in use at the Radioactive Waste Management Complex would be required by the design/build vendor's design. There were no additional supporting analyses conducted.

\subsubsection{Resolved Reconciliation Items}

\subsubsection{Schedule acceleration.}

- In the design/build proposals, the potential exists for conducting concurrent contractor and DOE operational readiness reviews. Although DOE Order 425.1D allows "specific events significant to the startup and restart process that occur prior to the formal commencement of the DOE ORR; e.g., site emergency response drills, to be reviewed by the DOE ORR team at the time they are conducted," it does not contemplate the DOE operational readiness review occurring in parallel with the contractor operational readiness review. In fact, the order requires the contractor to notify DOE that readiness to startup has been verified by the contractor operational readiness review prior to initiating the DOE 
operational readiness review. Based on these requirements, it is not viable to concurrently conduct the DOE and contractor operational readiness reviews.

The project baseline incorporates adequate time for sequential completion of the contractor management self assessment, contractor operational readiness review, and the DOE operational readiness review prior to receipt of startup approval. Further, the Federal Project Director recommends 4 weeks be included in the schedule (along with associated costs) to support resolution of pre-start findings prior to approval by the designated startup authority. The inclusion of additional time is particularly important because startup approval authority for new Hazard Category 2 facilities currently resides with the Secretary of Energy. This 4-week activity duration will be added in parallel with the planned 5-month CD-4 review period at a point following resolution of comments from the DOE operational readiness review.

- An analysis was performed of the CD-2/3 cost estimate and funding profile to determine if sufficient capital and operating funds are provided by the project data sheet to support the proposed design/build project schedule. Planned capital funding in Fiscal Year 2013 and Fiscal Year 2014 was found to be insufficient to allow full acceleration of the schedule. Delay of the construction portion of the project for 1 year would realign the schedule with the funding profile, but would cause an increase in escalation. Risk \#68 was added to the risk register to accommodate increased project cost for the project funding profile to support an accelerated schedule.

\subsubsection{Key performance parameters and project scope.}

- An assessment has been made to ensure the project key performance parameters can be met based on information provided by the vendors and the CD-2/3 documentation. However, the choice was made by the project to make the modified FTC cask optional scope. The cask will be returned to key scope on recommendation by the Federal Project Director. An assessment of the design/build vendor proposed vault scope has been compared to that assumed in developing the CD-2/3 performance baseline. Based on identified differences, management reserve/contingency was adjusted to allow conformance of the design/build vendor proposed scope to meet the key performance parameters (regardless of the bidder selected). Risk \#66 was added to the risk register to cover the cost of a potential scope gap. The amount of management reserve/contingency was verified to be adequate (see risk register for details and basis).

- An assessment of the equipment and procedures required to operate and commission the facility within the $\$ 35 \mathrm{M}$-cost cap provided to the design/build vendors was made to ensure all could be provided without DOE being required to fill in the gaps. The design/build vendors clarified the equipment to be provided during Phase I and Phase II as discussed in Section 3.5.4. Procedures and plans were discussed in Section 3.5.1 through 3.5.3.

\subsubsection{General.}

- The cost estimate, management reserve, and residual risk cost impact have been reevaluated and contingency and management reserve were adjusted. See the project execution plan (DOE-ID 2012) for these figures.

- The impacts of the proposed designs were assessed to determine whether they would require DOE to impose additional codes, standards, laws, or DOE requirements beyond those identified in the code of record (INL 2012b). DOE requested an assessment of List B requirements; those found to be appropriate were added to the code of record. The code of record will be reassessed and maintained during the life of the project.

\section{SUMMARY}

This reconciliation plan was developed to ensure the design/build vendor proposals would be adequately evaluated to verify that the CD-2/3 documentation is representative and bounding (e.g., PSDR, 
Safety Design Strategy, Preliminary Security Vulnerability Assessment, PA, and NEPA). If information was not available in the proposals, it was solicited in order to revise the CD-2/3 documentation prior to the Independent Project Review. Impacts of the proposed designs were assessed to determine whether they would require DOE to impose additional codes, standards, laws, or DOE requirements beyond those identified in the code of record (INL 2012b). An assessment was made to ensure the design/build proposals had not introduced risks that were not included in the risk management plan (PLN-2541) or performance baseline.

The cost estimate, management reserve, and residual risk cost impact were reevaluated and contingency and management reserve were adjusted as appropriate. The schedule of values was assessed to ensure it correlates with the funding profile.

Based on this reconciliation, issues requiring further tracking through final design or operational commissioning were identified. Resolutions to the issues will be added to this report as they are identified and implemented.

\section{REFERENCES}

10 CFR 830.204, "Documented Safety Analysis," Code of Federal Regulations

DOE-ID, 2012, Project Execution Plan for the Remote-Handled Low-Level Waste Disposal Project, DOE/ID-11466, Idaho National Laboratory, June 2012

DOE Order 413.3B, "Program and Project Management for the Acquisition of Capital Assets," U.S. Department of Energy

DOE Order 420.1B, “Facility Safety,” U.S. Department of Energy

DOE Order 425.1C, "Startup and Restart of Nuclear Facilities.” U.S. Department of Energy

DOE Order 425.1D, "Verification of Readiness to Start Up or Restart Nuclear Facilities," U.S. Department of Energy

DOE Order 435.1, "Radioactive Waste Management,” U.S. Department of Energy

INL, 2010a, Conceptual Design Report for the Remote-Handled Low-Level Waste Disposal Project, INL/EXT-07-12901, Idaho National Laboratory, April 2010

INL, 2010b, Conceptual Safety Design Report for the Remote-Handled Low-Level Waste Disposal Project, INL/EXT-09-17427, Idaho National Laboratory, February 2010

INL, 2010c, Preliminary Hazard Assessment for the Remote-Handled Low-level Waste Disposal Facility, INL/EXT-07-12903, Idaho National Laboratory, April 2010

INL, 2012a, Preliminary Safety Design Report for the Remote Handled Low-Level Waste Disposal Project, INL/EXT-10-19054, Idaho National Laboratory, March 2012

INL, 2012b, Remote-Handled Low-Level Waste Disposal Project Code of Record, INL/EXT-10-20044, Idaho National Laboratory, June 2012

INL, 2012c, Assessment of Potential Risks and Mitigation for the DOE O 435.1 Requirements AND THE NEPA Environmental Assessment for the RH-LLW Disposal Project, INL/EXT-12-26142, May 2012 
LWP-7460, "Project Turnover and Acceptance," Idaho National Laboratory

LWP-9903, "Performing Management Self-Assessments for Readiness,” Idaho National Laboratory

PLN-2541, "Remote-Handled Low-Level Waste Disposal Project Risk Management Plan,” Idaho National Laboratory, June 2012

SPC-1437, 2012, "Design-Build-Operate Performance Specification for the Remote-Handled Low-Level Waste Disposal Project," Project No. 31055, January 12, 2012

TFR-483, 2012, "Technical and Functional Requirements, Remote-Handled Low-Level Waste Disposal Project," Project No. 31055, January 16, 2012. 